\title{
Expression of Calponin 3 in the Striatum Following 3-Nitropropionic Acid-induced Neurotoxicity
}

\author{
Yun-Sik Choi*
}

\author{
Department of Pharmaceutical Science and Technology, Catholic University of Daegu, 712-702 Gyeongsansi, Gyeongsangbuk-do, Korea
}

Received December 11, 2012 /Revised December 27, 2012 / Accepted December 28, 2012

\begin{abstract}
Calponin 3 is an F-actin-binding protein and plays a key role in regulating spine plasticity and synaptic activity in neurons. Unlike the other subtypes, calponin 1 and 2, which are expressed in smooth and cardiac muscle cells, calponin 3 is highly expressed in the brain. The goal of this study was to elucidate the spatiotemporal expression pattern of calponin 3 following repeated administration of 3-nitropropionic acid in mice. The repeated administration of 3-nitropropionic acid generated necrotic neuronal cell death in the striatum. Calponin 3 was up-regulated in the neuroprotective penimbral region from 1.5 days after the last injection and thereafter. Double immunofluorescence study revealed that calponin 3 was induced in GFAP-positive astrocytes. These results suggest that calponin 3 induction in the neuroprotective penumbral area following 3-nitropropionic acid intoxication may play a key role in reactive astrogliosis in the striatum.
\end{abstract}

Key words : Calponin 3, 3-nitropionic acid, astrocyte, striatum, Huntington's disease

\section{Introduction}

Calponin is an actin filament-associated regulatory protein expressed in diverse types of cells including smooth muscle cells. Three isoforms of calponin, calponin 1 (acidic calponin), calponin 2 (neutral calponin) and calponin 3 (acidic calponin) have been known in vertebrates. Although the role of calponin in regulating smooth muscle contractility has been extensively investigated, the function and regulation of calponin in non-muscle cells is much less understood [17].

Calponin 1 and calponin 2 are predominately expressed in smooth muscle cells and cardiac muscle cells, respectively. On the other hand, calponin 3 is highly expressed in many tissues including articular cartilage and brain [6, 11]. In the central nervous system, calponin 3 is co-localized with PSD95, NR1 and GluR1. Postsynaptic over-expression of calponin 3 enhances the frequency of miniature excitatory postsynaptic currents by reorganizing the actin filaments [12]. These data indicate that calponin 3 may play an important role in regulating spine plasticity and synaptic activity.

\section{*Corresponding author}

Tel : +82-53-850-2561, Fax : +82-53-850-2504

E-mail : tiana@cu.ac.kr

This is an Open-Access article distributed under the terms of the Creative Commons Attribution Non-Commercial License (http://creativecommons.org/licenses/by-nc/3.0) which permits unrestricted non-commercial use, distribution, and reproduction in any medium, provided the original work is properly cited
Interestingly, it has been reported that the expression of calponin 3 is increased in the brain of epileptic patients and experimental rats. In addition, the elevation level of calponin 3 in the cerebrospinal fluid (CSF) was highly correlated with disease duration [7]. Further, calponin 3 immunoreactivity was clearly increased in the inner one-third of the molecular layer of the dentate gyrus at 1 and 2 weeks after pilocarpine-induced seizures, which indicates that calponin 3 is involved in mossy fiber sprouting and neo-synaptogenesis [5]. Taken together, it is believed that calponin 3 is involved in pathogenesis and remodeling of the central nervous system by regulating morphology of axon and dendrites, and its activity.

To further elucidate the role of calponin 3 in neuropathology, a mouse model of 3-nitropropionic acid (3-NP)induced striatal neurotoxicity was employed. Systemic administration of 3-NP induces blockade of mitochondrial complex II and decreases ATP level within the brain, which preferentially induces excitotoxic striatal neurodegeneration with behavioral abnormalities reminiscent of Huntington's disease [1-3, 10]. In addition, the pattern of striatal lesions is similar to that seen in Huntington's disease patients. Therefore, 3-NP-induced striatal neurotoxicity is generally accepted as an animal model of HD-like symptoms. The present study was designed to investigate the involvement of calponin 3 in 3-NP-induced striatal neurotoxicity in mice. 


\section{Materials and Methods}

\section{Animals}

Male C57BL/ 6 mice (8 weeks old, Koatech, Kyungki-do, Korea) were housed at a standard temperature $\left(22 \pm 1^{\circ} \mathrm{C}\right)$, humidity $(50 \pm 1 \%)$, and in a light-controlled environment (lights on from 8:00 a.m. to 8:00 p.m.) with ad libitum access to food and water. The animal experiments were carried out in accordance with the National Institutes of Health Guide for the Care and Use of Laboratory Animals $(\mathrm{NIH}$ Publication No. 80-23, revised 1996). Efforts were made to try to minimize animal suffering and to reduce the number of animals used.

\section{3-nitropropionic acid (3-NP) intoxication}

3-nitropropionic acid (3-NP, Sigma, St. Louis, MO) was dissolved in saline $(25 \mathrm{mg} / \mathrm{ml})$ and passed through a $0.2-\mu \mathrm{m}$ filter. We followed the 3-NP injection protocol described by Huang et al. [8]. Briefly, 3-NP was injected intraperitoneally twice daily for 2 days at 12-h intervals (10:00 a.m. and 10:00 p.m.) at a dose of $60 \mathrm{mg} / \mathrm{kg}$ for the first two injections and
$80 \mathrm{mg} / \mathrm{kg}$ for the second two injections. Animals were maintained on a standard 12-h light/dark cycle, with lights on at 8:00 a.m.

\section{Tissue processing}

Mice were anesthetized with $15 \%$ chloral hydrate and transcardially perfused with saline, followed by $4 \%$ paraformaldehyde in $0.1 \mathrm{M}$ phosphate buffer (PB), $\mathrm{pH}$ 7.4. Brains were postfixed for 4 hours and then cryoprotected in 30\% sucrose in $0.1 \mathrm{M}$ PB. Sequential coronal sections (30 $\mu \mathrm{m}$ thick) through the striatum were prepared using a cryotome.

\section{Immunohistochemistry and immunofluorescence}

For immunohistochemical labeling, sections were blocked with $10 \%$ normal goat serum in PBS, followed by overnight incubation $\left(4^{\circ} \mathrm{C}\right)$ with rabbit polyclonal anti-calponin 3 antibody (1:500; Santa Cruz, CA). Sections were then processed using the $\mathrm{ABC}$ staining method (Vector Laboratories, Burlingame, CA) and diaminobenzidine (DAB; Vector Laboratories) was used to visualize the signal.

For immunofluorescence labeling, sections were blocked
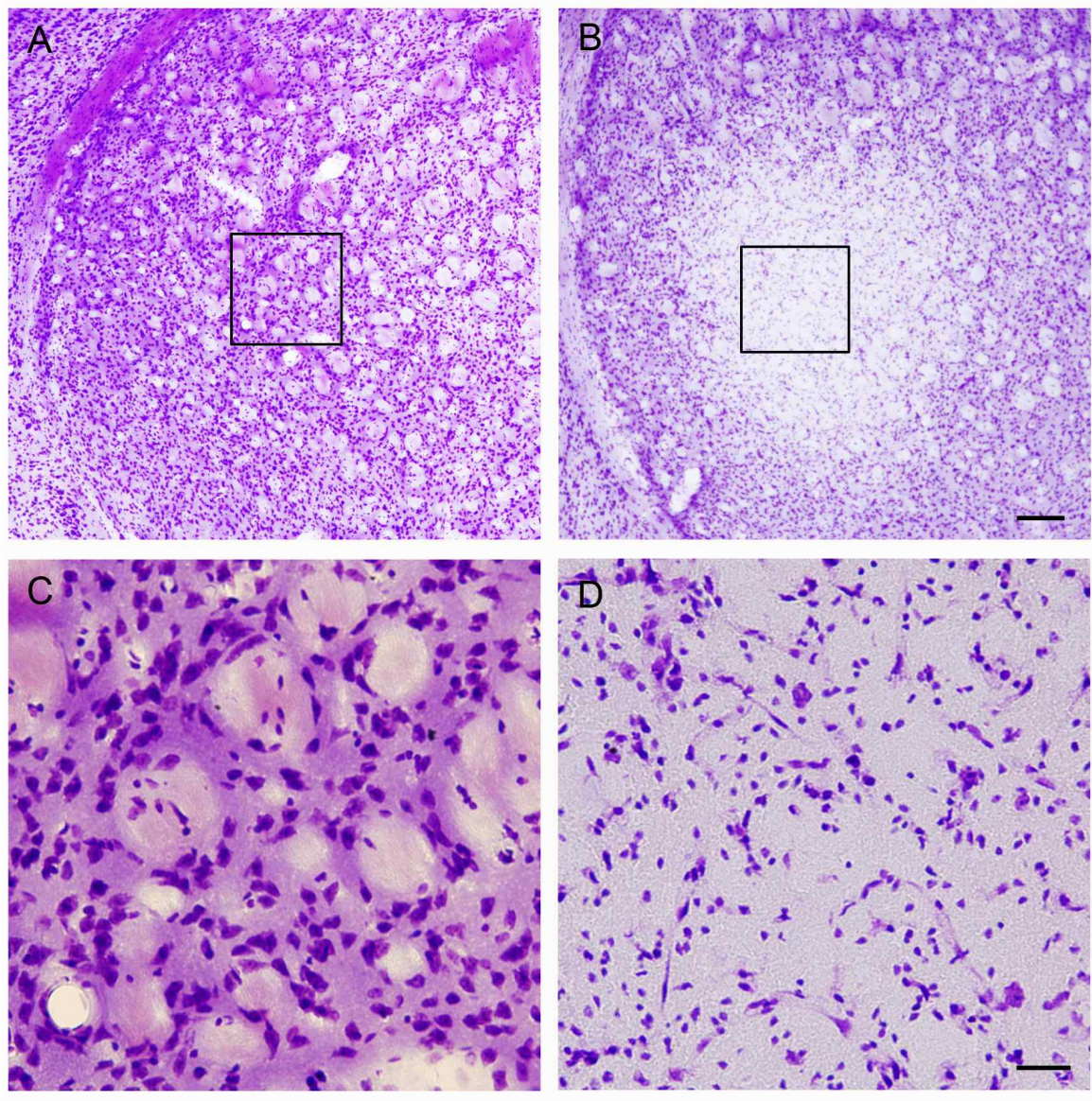

Fig. 1. 3-Nitropropionic acid intoxication induces necrotic cell death in the striatum. (A-B) Cresyl violet histology reveals marked cell damage within the lateral striatum. Tissues were collected from control (saline injected: A) or 3 days after last 3-nitropropionic acid injection (B). Boxed areas in $A$ and $B$ were magnified in $C$ and $D$, respectively. Scale bars are $200 \mu \mathrm{m}$ and $50 \mu \mathrm{m}$ in B and $\mathrm{D}$, respectively. 
with $10 \%$ normal goat serum, followed by overnight incubation with rabbit polyclonal anti-calponin 3 antibody (1:500) and mouse anti-GFAP antibody (1:500; Chemicon, Temecula, CA) or anti-NeuN antibody (1:500; Chemicon). Next, sections were incubated ( $2 \mathrm{~h}$ at room temperature) with secondary antibodies conjugated with Alexa 488 and Alexa 594 (1:1000; Invitrogen, San Diego, CA) and then mounted with Cytoseal (Richard-Allan Scientific, Kalamazoo, MI). Fluorescence images were captured using a Zeiss (Oberkochen, Germany) 510 Meta confocal microscope (2um-thick optical section).

\section{Cresyl violet staining}

In brief, sections were mounted on gelatin-coated slides and dried. After dehydrating in a graded alcohol series, sections were stained $(20 \mathrm{~min})$ with $0.1 \%$ cresyl violet solution. After destaining with solution of $95 \%$ ethanol and $0.1 \%$ gla- cial acetic acid, sections were dehydrated and mounted with Permount.

\section{Results}

\section{Generation of 3-nitropropionic acid-induced striatal} injury

As introduced in the previous report, 3-nitropropionic acid, a mitochondrial toxin, was used to induce striatal injury [4]. 3-nitropropionic acid was given at 12-h intervals as a dose of $60 \mathrm{mg} / \mathrm{kg}$ for the first two injections and 80 $\mathrm{mg} / \mathrm{kg}$ for the second two. First, striatal damage was tested with cresyl violet which stains viable cells. As shown in Fig. 1 , marked tissue damage was observed in the lateral striatum at 3 days after last injection. The pattern of tissue damage was consistent between animals showing core region with concentrated neuronal damage.
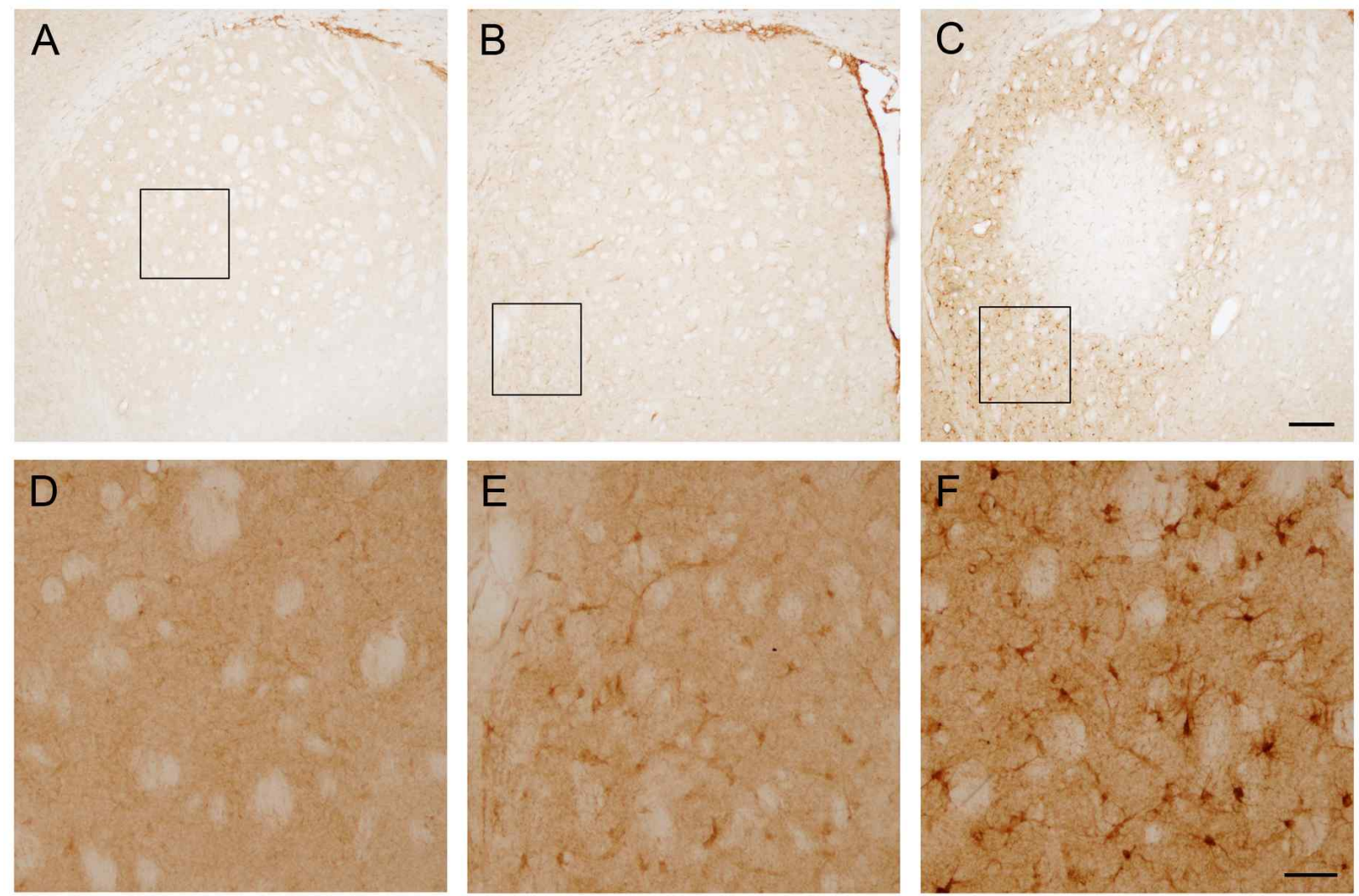

Fig. 2. Calponin 3 induction following 3-nitropropionic acid in the striatum. (A) Representative images of calponin 3 in the striatum under normal condition. The image shows minimal immunoreactivity throughout the striatum. Boxed area was magnified in D. (B) Calponin 3 expression at 1.5 days after last 3-nitropropionic acid injection. Calponin 3 immunoreactivity was increased compared to normal striatum. Boxed area was magnified in E. (C) Representative image showing increased expression of calponin 3 in the striatum at 3 days after last 3-nitropropionic acid injection. Compared to calponin 3 immunoreactivity at 1.5 days after 3-nitropropionic acid injection, calponin 3 expression level was strongly increased in the penumbral region. Boxed bar was magnified in F. Scale bars are $200 \mu \mathrm{m}$ and $50 \mu \mathrm{m}$ in $\mathrm{C}$ and $\mathrm{F}$, respectively. 
Increased expression of calponin 3 following 3-nitropionic acid-induced striatal damage

Calponin 3 expression was examined by immunohistochemistry with calponin 3 antibody. As shown in Figs. 2A and 2D, expression level of calponin 3 was low in normal tissue. However, slightly increased calponin 3 expression was observed at 1.5 days after last injection (Figs. 2B and $2 \mathrm{E})$. At 3 days after last injection strong expression of calponin 3 was observed in the striatum (Figs. $2 \mathrm{C}$ and $2 \mathrm{~F}$ ). At this time point calponin 3 expression was strongly observed in the penumbral region where neurons are resistant to 3-nitropropionic acid injection. In contrast there was no regional pattern of calponin 3 expression at 1.5 days post last injection.

Induction of calponin 3 expression in reactive astrocyte

Next, double immunolabeling was performed to examine cell types expressing high levels of calponin 3. For this purpose antibodies against GFAF, an astrocytic marker, or NeuN, a neuronal marker, were used. As shown in Fig. 3A, calponin 3 expressing cells were not co-labeled with NeuN-positive neurons. On the other hand, calponin 3 was double-labeled with GFAP suggesting that calponin-3 is induced in reactive astrocytes following 3-nitropropionic acid-induced tissue damage.

\section{Discussion}

In this study, the initial finding was that calponin 3 is expressed in the striatum following 3-NP-induced striatal neurotoxicity. The expression of calponin 3 occurred at 1.5 days and thereafter, and its expression was preferentially observed in resistant penumbral areas rather than the necrotic core. In addition, calponin 3 was induced in GFAP-positive reactive astrocytes rather than in neurons.

Calponin was originally discovered in chicken gizzard smooth muscle as an actin- and calmodulin-binding protein [13]. It has been known that calponin interacts with F-actin, calmodulin, and tropomyosin, and functionally regulates the contraction and relaxation cycles in smooth muscle [14, 15]. In addition, calponin induces actin polymerization and stabilizes formed actin filaments resulting in the maintenance of stress fibers [9]. Although calponin 1 and 2 are predominantly expressed in smooth muscle cells, calponin 3 is highly expressed in the central nervous system and its expression level is increased in neuropathologic conditions such as epilepsy. In the central nervous system calponin 3 protein and its mRNA are mainly expressed in neurons under normal conditions [11]. Interestingly, calponin 3 is co-localized with PSD95, GluR1 and NR1 in the central nervous system and over-expression of calponin 3 in the cultured hippocampal neurons enhances the frequency of miniature ex-

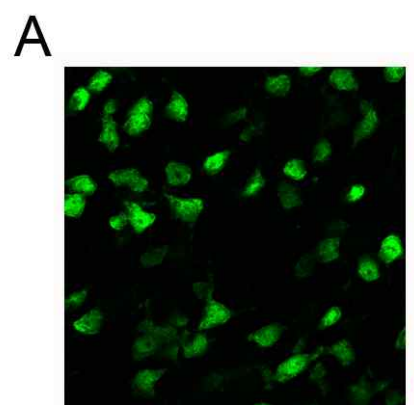

NeuN

B

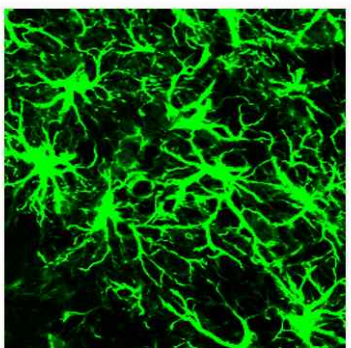

GFAP

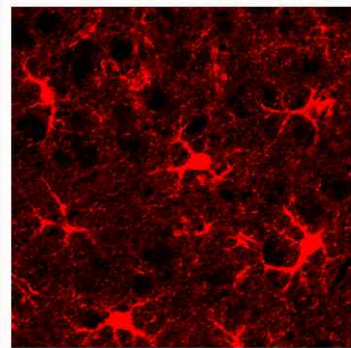

Calponin 3

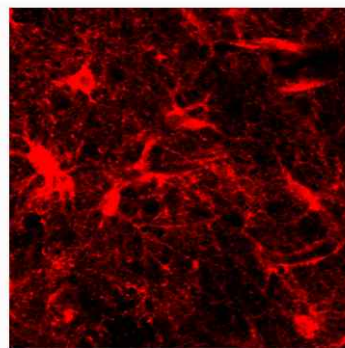

Calponin 3

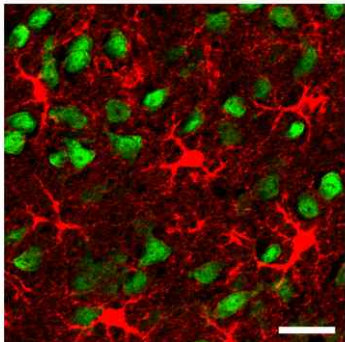

Merged

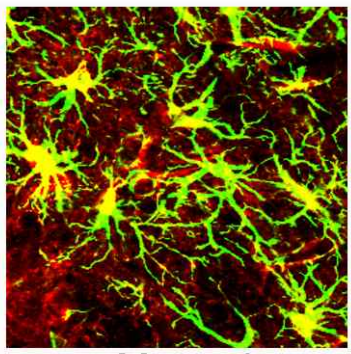

Merged
Fig. 3. Calponin 3 expression in the reactive astrocytes following 3-nitropropionic acid-induced striatal neurotoxicity. (A) Double immunofluorescence labeling with calponin 3 (red) and NeuN (green), a neuronal marker, was performed. However, there were no double-labeled cells, suggesting that calponin 3 was not induced in the striatal neurons. (B) Double immunolabeling with calponin 3 (red) and GFAP (green), an astrocyte marker, was performed. Representative reveals that calponin 3 is strongly induced in reactive astrocytes. Scale bar is $20 \mu \mathrm{m}$. 
citatory postsynaptic currents. Thus, it has been postulated that calponin 3 is a key factor in regulating spine plasticity and synaptic activity [12]. One of the important findings in this study is that the expression of calponin 3 is strongly and predominantly induced in GFAP-positive reactive astrocytes in the resistant penumbral region following repeated 3-NP administration.

Intoxication with 3-NP results in asymmetric activation of transcriptional pathways, gene expression and cell vulnerability between neuroprotective penumbral and necrotic core regions. For example, the CREB/CRE-mediated transcriptional pathway is activated in the penumbral area but not in the necrotic core [4]. Likewise, the neuroprotective protein $\mathrm{Bcl}-2$ is preferentially induced in neurons from the penumbral region and those neurons are protected[4]. Along these lines, in this study reactive astrocyte strongly expressing GFAP was preferentially observed in the penumbral region and these astrocytes were co-labeled with calponin 3. Previously, it has been reported that in case of epileptic patients expression level of calponin 3 was increased in MAP2-positive neurons [7]. In addition, in animal models of epilepsy with pilocarpine, calponin 3 immunoreactivity was specifically increased in the inner one-third of the molecular layer of the dentate gyrus and double immunolabeling revealed that calponin 3 was localized in the dendritic spines. Therefore, although there have been several reports showing calponin 3 expression in astrocytes under a normal state (see below), this is the first report showing strong induction of calponin 3 in astrocytes under pathologic conditions.

The expression of calponin 3 in astrocytes under normal conditions is controversial. For example, it was reported that calponin 3 is expressed in radial glia, glia limitans, Bergmann glia and mature astrocytes in postnatal rat brains, although it was absent in mature astrocytes in culture [11]. In addition, in the human cortices faint calponin-3 staining was reported in astrocytes [7]. Further, cultured cortical astrocytes express calponin heterogeneously [16]. Therefore, one may postulate that calponin 3 is highly expressed in the astrocyte during brain development and its expression level is gradually decreased. Supporting this idea, in this study calponin 3 immunoreactivity in the astrocytes was not evident under normal conditions.

Next, the role of calponin 3 in reactive astrocyte is unclear. Astrocytes respond to CNS insults and change morphology, gene expression and form scars (which is called reactive as- trogliosis). Thus, reactive astrocytes organize neuronal injury responses, inflammation, and repair. It has been reported that during development calponin 3 is observed at the growing tips of astrocytes, and this may suggest the role of calponin 3 in the elongation of glial processes [11]. Since elongation of processes is one of the main morphological changes in reactive astrocytes, enrichment of calponin 3 in reactive astrocytes is compatible with the hypothesis that calponin 3 contributes to the morphological maturation into reactive astrocytes following 3-NP-induced striatal neurotoxicity. However, further study will be needed to elucidate the role of calponin 3 in reactive astrocytes.

In summary, the data provided here reveal for the first time increased expression of calponin 3 in the astrocytes in the resistant penumbral region following 3-NP-induced neurotoxicity. Given the role of astrocytes during neurodegeneration, understanding the role of calponin 3 may provide insight into the striatal pathogenesis in HD and eventual therapeutic tools.

\section{Acknowledgement}

This research was supported by research grants (\#20121390) from the Catholic University of Deagu in 2012.

\section{References}

1. Beal, M. F., Brouillet, E., Jenkins, B., Henshaw, R., Rosen, B. and Hyman, B. T. 1993. Age-dependent striatal excitotoxic lesions produced by the endogenous mitochondrial inhibitor malonate. J Neurochem 61, 1147-1150.

2. Brouillet, E., Jenkins, B. G., Hyman, B. T., Ferrante, R. J., Kowall, N. W., Srivastava, R., Roy, D. S., Rosen, B. R. and Beal, M. F. 1993. Age-dependent vulnerability of the striatum to the mitochondrial toxin 3-nitropropionic acid. $J$ Neurochem 60, 356-359.

3. Calkins, M. J., Vargas, M. R., Johnson, D. A. and Johnson, J. A. 2010. Astrocyte-specific overexpression of Nrf2 protects striatal neurons from mitochondrial complex II inhibition. Toxicol Sci 115, 557-568.

4. Choi, Y. S., Lee, B., Cho, H. Y., Reyes, I. B., Pu, X. A., Saido, T. C., Hoyt, K. R. and Obrietan, K. 2009. CREB is a key regulator of striatal vulnerability in chemical and genetic models of Huntington's disease. Neurobiol Dis 36, 259-268.

5. Ferhat, L., Esclapez, M., Represa, A., Fattoum, A., Shirao, T. and Ben-Ari, Y. 2003. Increased levels of acidic calponin during dendritic spine plasticity after pilocarpine-induced seizures. Hippocampus 13, 845-858.

6. Haag, J. and Aigner, T. 2007. Identification of calponin 3 as a novel Smad-binding modulator of BMP signaling ex- 
pressed in cartilage. Exp Cell Res 313, 3386-3394.

7. Han, Y., Yin, H., Xu, Y., Zhu, Q., Luo, J., Wang, X. and Chen, G. 2012. Increased expression of calponin-3 in epileptic patients and experimental rats. Exp Neurol 233, 430-437.

8. Huang, Q. Y., Wei, C., Yu, L., Coelho, J. E., Shen, H. Y., Kalda, A., Linden, J. and Chen, J. F. 2006. Adenosine A2A receptors in bone marrow-derived cells but not in forebrain neurons are important contributors to 3-nitropropionic acid-induced striatal damage as revealed by cell-type-selective inactivation. $J$ Neurosci 26, 11371-11378.

9. Kake, T., Kimura, S., Takahashi, K. and Maruyama, K. 1995. Calponin induces actin polymerization at low ionic strength and inhibits depolymerization of actin filaments. Biochem J 312, 587-592.

10. Kumar, P., Kalonia, H. and Kumar, A. 2011. Role of LOX/COX pathways in 3-nitropropionic acid-induced Huntington's disease-like symptoms in rats: protective effect of licofelone. Br J Pharmacol 164, 644-54.

11. Plantier, M., Fattoum, A., Menn, B., Ben-Ari, Y., Der Terrossian, E. and Represa, A. 1999. Acidic calponin immunoreactivity in postnatal rat brain and cultures: subcellular localization in growth cones, under the plasma membrane and along actin and glial filaments. Eur J Neurosci 11, 2801-2812.

12. Rami, G., Caillard, O., Medina, I., Pellegrino, C., Fattoum, A., Ben-Ari, Y. and Ferhat, L. 2006. Change in the shape and density of dendritic spines caused by overexpression of acidic calponin in cultured hippocampal neurons. Hippocampus 16, 183-197.

13. Takahashi, K., Hiwada, K. and Kokubu, T. 1986. Isolation and characterization of a 34,000-dalton calmodulin- and F-actin-binding protein from chicken gizzard smooth muscle. Biochem Biophys Res Commun 141, 20-26.

14. Takahashi, K., Hiwada, K. and Kokubu, T. 1988. Vascular smooth muscle calponin. A novel troponin T-like protein. Hypertension 11, 620-626.

15. Takahashi, K. and Nadal-Ginard, B. 1991. Molecular cloning and sequence analysis of smooth muscle calponin. $J$ Biol Chem 266, 13284-13288.

16. Tomé, M., Siladzic, E., Santos-Silva, A. and Barnett, S. C. 2007. Calponin is expressed by subpopulations of connective tissue cells but not olfactory ensheathing cells in the neonatal olfactory mucosa. BMC Neurosci 18, 74.

17. $\mathrm{Wu}, \mathrm{K}$. C. and Jin, J. P. 2008. Calponin in non-muscle cells. Cell Biochem Biophys 52, 139-148.

초록 : 선조체에서 3-nitropropionic acid 투여 후 calponin 3의 발현 연구

최윤식*

(대구가톨릭대학교 제약산업공학과)

Calponin 3는 F-actin과 결합하는 단백질로 신경계의 가소성과 시냅스 활성을 조절하는데 중요한 역할을 하는 것으로 알려져 있다. 평활근과 심장근에 발현되는 calponin 1과 calponin 2와는 다르게 calponin 3 는 뇌 조직에 많이 발현되어 있는 것으로 보고되고 있다. 본 연구는 마우스에서 3-nitropropionic acid를 투여하여 선조체에 비 가역적 신경 손상을 주었을 때 calponin 3의 발현 양상을 알아보기 위하여 진행되었다. 본 연구 결과 3-nitropropionic acid를 마우스에 투여하였을 때 선조체에서 신경조직의 괴사가 일어남을 관찰하였으며 calponin 3는 약물 투여 후 1.5 일부터 서서히 발현되는 것을 확인하였다. 특히, calponin 3 는 신경조직의 괴사가 일어나는 부위 의 주변부에서 발현되는 것을 확인하였으며 형광 이중면역 염색법으로 확인한 결과 GFAP를 발현하는 별아교세 포에서 발현됨을 최초로 밝혔다. 따라서, calponin 3가 3-nitropropionic acid의 독성에 저항성을 나타내는 부위에 서 별아교세포에서만 특이적으로 발현되는 것으로 보아 calponin 3 는 별아교세포에 의한 신경아교증에 중요한 역할을 하는 것으로 추측된다. 